\title{
Determination of Hydrocarbon Potentials Using High Resolution Aeromagnetic Data over Sokoto Basin, Northwestern Nigeria
}

\author{
Ezekiel Kamureyina \\ Department of Geology and Mining, Adamawa State University, Mubi, Nigeria \\ Email: ezekielkamureyina@yahoo.com
}

How to cite this paper: Kamureyina, E. (2019) Determination of Hydrocarbon Potentials Using High Resolution Aeromagnetic Data over Sokoto Basin, Northwestern Nigeria. International Journal of Geosciences, 10, 419-438.

https://doi.org/10.4236/ijg.2019.104024

Received: January 21, 2019

Accepted: April 21, 2019

Published: April 24, 2019

Copyright $\odot 2019$ by author(s) and Scientific Research Publishing Inc. This work is licensed under the Creative Commons Attribution International License (CC BY 4.0).

http://creativecommons.org/licenses/by/4.0/

\section{(c) (i) Open Access}

\begin{abstract}
Aeromagnetic method of exploration is famed for its suitability for locating buried magnetic ore bodies because of their magnetic susceptibility. This method has been used in the early stage of petroleum exploration to determine depth and major structures of crystalline Basement rocks underlying the sedimentary basin. In this study, high resolution aeromagnetic data were used to ascertain the viability for hosting hydrocarbon potentials of the study area which forms part of the Illummeden Basin (also known locally as the Sokoto embayment) of West Africa. This was largely carried out through Spectra analysis to determine sediment thickness. The results of the analysis of the aeromagnetic data show that, deeper magnetic source ranges from $0.41 \mathrm{~km}$ to $2.69 \mathrm{~km}$, shallow magnetic sources from $0.17 \mathrm{~km}$ to $0.97 \mathrm{~km}$. Areas with shallow sediment thickness could not allow the thermal maturation of the sediments, since temperature increase with depth and a depth of two kilometers and above has a temperature range of $60^{\circ} \mathrm{C}$ and above. Areas with sediment thickness of $1.5 \mathrm{~km}$ and above were delineated and considered as sub-basins and hence potential areas for hydrocarbon exploration.
\end{abstract}

\section{Keywords}

Hydrocarbon Potentials, High Resolution Aeromagnetic Data, Spectral Analysis, Sokoto Basin, Nigeria

\section{Introduction}

The present work determines the potentials of the study area for hydrocarbon, based on the high resolution digital aeromagnetic data over Sokoto basin, indi- 
cating that the basin is characterized by shallow and deeper sediments thickness. Areas with shallow sediments thickness could not allow the thermal maturation of the sediments since temperature increase with depth and a depth of two kilometer and above has a temperature range of $60^{\circ} \mathrm{C}$ and above [1]. The determination of hydrocarbon potentials was carried out using statistical spectral method as a tool for determining depth to magnetic sources.

Most economic minerals, oil, gas, and groundwater lie concealed beneath the earth surface, thus hidden from direct view. The presence and magnitude of these resources can only be ascertained by geophysical investigations of the subsurface geologic structures in the area. If the area under investigation has no previous geological information and the primary aim of the study is to search for hydrocarbon deposits; the first question that must be answered, is whether the sedimentary basin is large enough and thick enough to justify any further investigations [2].

The aim of a magnetic survey is to investigate subsurface geology on the basis of magnetic anomalies in the Earth's magnetic field resulting from the magnetic properties of the underlying rocks [3]. Aside from the principal objective in assisting for mineral and groundwater development through improved geologic mapping, aeromagnetic surveys have traditionally been applied at the early stage of petroleum exploration to determine depth and major structures of Crystalline Basement rocks underlying the Sedimentary basin.

In this study, high resolution aeromagnetic data were used to ascertain the viability of the area for hydrocarbon. The possible occurrence of minerals, oil and gas in commercial quantities in the Sokoto basin has been a subject of controversy due to very scanty prospectivity data. Apart from the Niger Delta basin whose current production of petroleum is derived, Nigeria is blessed with other numerous Sedimentary basins comprising the Anambra, Bida, Sokoto, Borno (Chad) and Dahomey basins as well as the Benue trough which is made up of Lower, Middle and upper Benue troughs; these basins have structural and stratigraphical similarities with contiguous intracratonic rifted basins of Niger Republic, Chad Republic, Sudan, Uganda, Tanzania and Kenya where commercial oil accumulations have been discovered and currently been exploited [4].

The aim of this work is to analyze and interpret the high resolution aeromagnetic data over the study area: to determine the thickness of the sediments through Spectral analysis. The work is aimed at acquainting future researchers with the knowledge of the area and to shed more light on sediment thickness which is crucial to hydrocarbon generation in the study area.

The study area lies between longitudes $4^{\circ} 00^{\prime} \mathrm{E}$ and $6^{\circ} 00^{\prime} \mathrm{E}$ and latitudes $11^{\circ} 30^{\prime} \mathrm{N}$ and $13^{\circ} 30^{\prime} \mathrm{N}$ (Figure 1). The topographical map of Figure 1 was obtained from digital elevation model (DEM) [5], and covers an area of approximately $48,400 \mathrm{~km}^{2}$. It is part of the Illummeden Basin of West Africa, locally known as the Sokoto embayment situated in northwestern Nigeria [6] and [7]. It consists predominantly of a gently undulating plain with an average elevation 


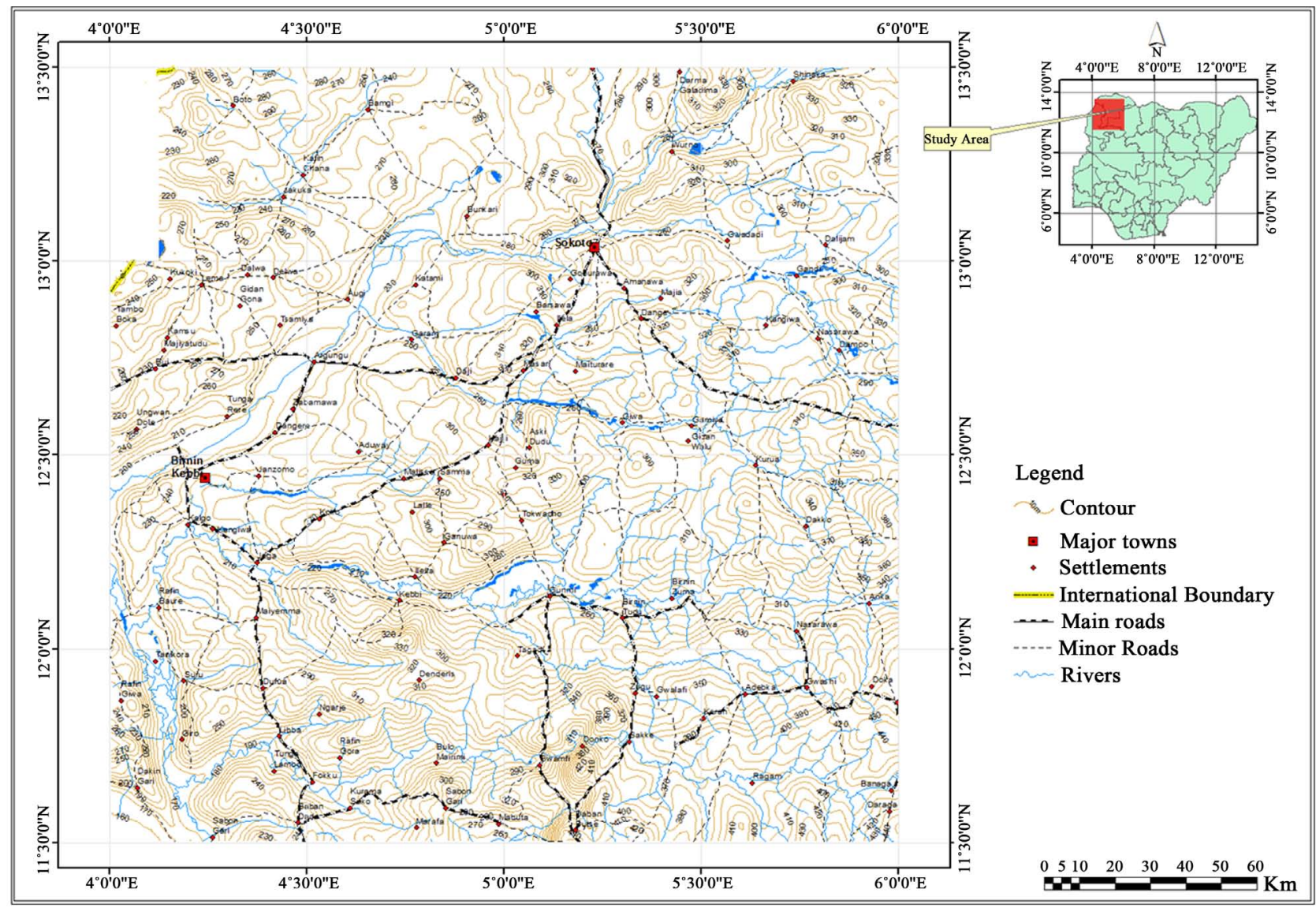

Figure 1. Topographic map of the study area [analyzed from Digital Elevation Model (DEM) 2006].

varying from 250 to $400 \mathrm{~m}$ above sea level. The plain is occasionally interrupted by low Mesas. A low Escarpment known as the "Dange Scarp" is the most prominent feature in the basin. The area to the east of the escarpment consists of mainly an undulating sandy plain, which extends south-westwards to the outcropping basement complex [8].

The Sokoto basin falls within the hottest parts of Nigeria, belonging to the Sahel region of Africa. Temperatures are generally extreme, with average daily minimum of $16^{\circ} \mathrm{C}$, during cool months of January and December, and the hottest months of April to June with an average maximum of $38^{\circ} \mathrm{C}$ and minimum of $24^{\circ} \mathrm{C}$. Throughout the year average minimum temperature is $36^{\circ} \mathrm{C}$ and average daily minimum is $21^{\circ} \mathrm{C}$. Rainfall is generally low with mean annual rainfall ranging from $600 \mathrm{~mm}$ to $1000 \mathrm{~mm}$ across the Basin. Much of the rain falls between the months of May to September, while the dry months are October to April [7].

The geology of Sokoto Basin is very well documented by several authors such as [4], [6], [8], [9] and [10]. According to [11], the geology of the study area (Figure 2) consists of Younger Basalts; Gwandu Formation; Sokoto group consisting of Gamba Formation, Kalambaina Formation and Dange Formation; Rima group consisting of Wurno Formation, Dukamaje Formation and Taloka Formation; Illo Formation, Gundumi Formation; Pan-African Younger Granitoids and Migmatite-Gneiss Complex. 


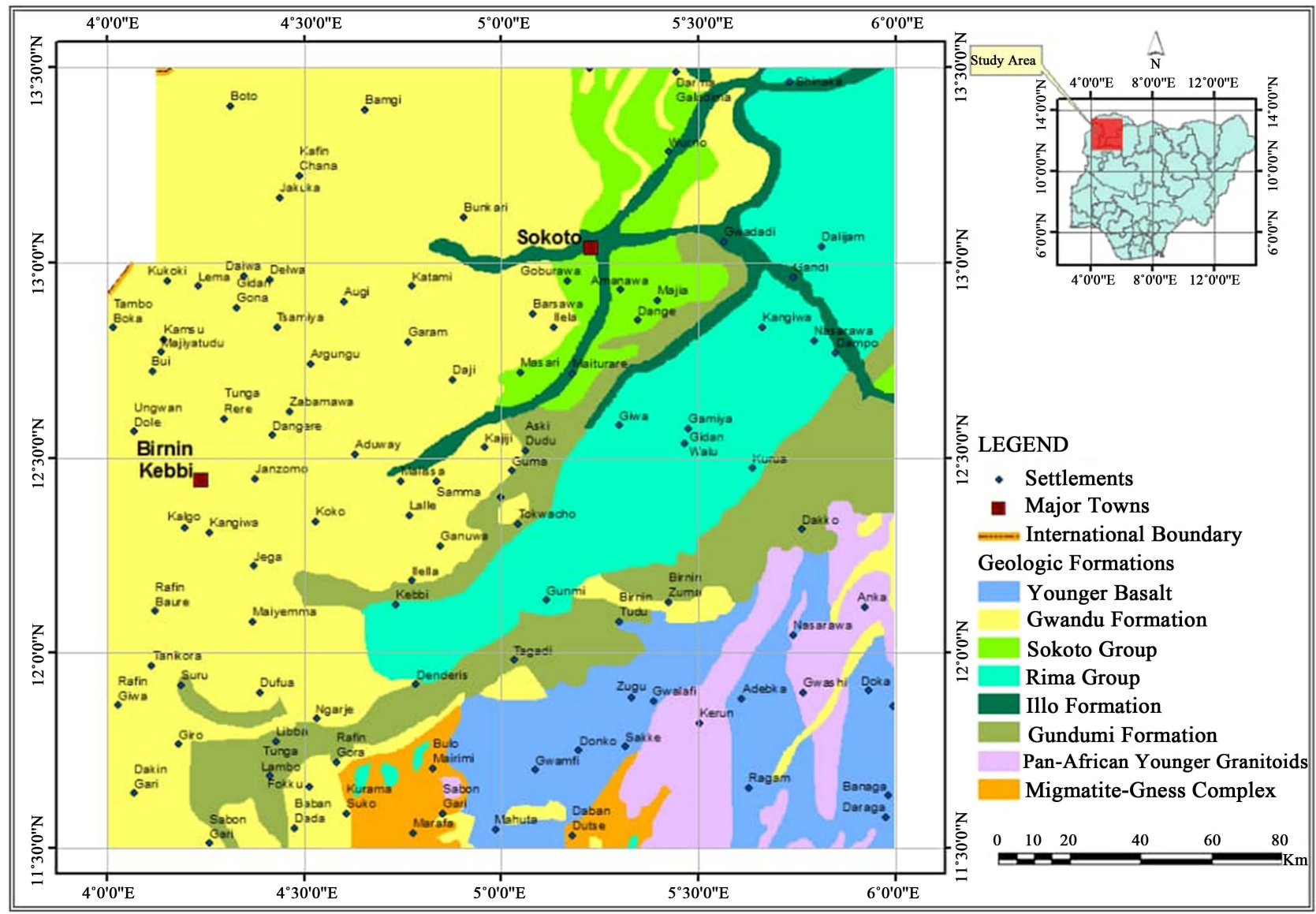

Figure 2. Geologic map of the study area (after Nigerian geologic survey agency, 2006).

The sediments of the Sokoto basin were accumulated during different phases of deposition. Overlying the Pre-Cambrian Basement unconformably, is the Illo and Gundumi Formations which are made up of grits and clays, constitute the Pre-Maastrichtian "Continental Intercalaire" of West Africa. They are overlain unconformably by the Maastrichtian Rima Group, consisting of Mudstones and friable Sandstones of Taloka and Wurno Formations separated by the fossiliferious, calcareous and shaley Dukamaje Formation. The Dange and the Gamba Formations which are mainly shales are separated by the calcareous Kalambaina Formation, which all constitute the Paleocene Sokoto Group. The overlying continental Gwandu Formation forms the Eocene Continental Terminal [4].

\section{Materials and Methods}

\subsection{Data Acquisition}

The high resolution aeromagnetic data that was used for the study consist of sixteen (16) sheets of aeromagnetic maps of total field intensity in half degree sheets obtained from Nigerian Geological Survey Agency (NGSA) [12]. The data was acquired by Fugro Airborne Survey Limited, as part of a programme aimed at assisting and promoting mineral exploration in Nigeria using $3 \times$ Scintrex CS3 Cesium Vapour Magnetometer with Flight Line Spacing of 500 meter, Flight 
Line Direction NW-SE, Terrain Clearance 80 meters, Tie Line Spacing 2 kilometres.

\subsection{Data Processing}

Data was processed using various filters on the Aeromagnetic data which revealed certain features that aid the interpretation. Thus the digitized data was imported into the computer to produce the total Magnetic intensity maps. The Total Magnetic data was further subjected to Polynomial filtering to obtain both the Regional and the Residual maps. Spectral analysis was used to determine average sediment thickness. All these were carried out using the Oasis montaj, Math lab, and ArcGIS software.

In polynomial fitting the regional is matched with mathematical Polynomial of low order to expose the residual features as random errors, and the treatment is based on statistical theory. The observed data are used to compute, usually by least square method, the mathematically described surface given the closet fit to the magnetic field that can be obtained within a specified degree of detail. This surface is considered to be the regional field and the residual is the difference between the magnetic field values thus determined [13]. The simplest approach is to fit a polynomial of first order to the magnetic data over a large area as possible around the zone of interest and to subtract the polynomial surface from the observed surface. If the regional field were a simple inclined plane it will be a first order surface. Thus

$$
Z=A x+B y+C
$$

The next stage of complexity is the representation of a second order polynomial where,

$$
Z=A x^{2}+B y^{2}+C x y D x+E y+F
$$

The residual magnetic field of the study area was produced by subtracting the regional field from the total magnetic field using the Polynomial fitting method. The computer program aero-super map was used to generate the coordinates of the total intensity field data values. This super data file, for all the magnetic values was used for production of composite aeromagnetic map of the study area using Oasis Montaj software version 7.0.1 [14]. The program was used to derive the residual magnetic values by subtracting values of regional field from the total magnetic field values to produce the residual magnetic map and the regional map.

There are different methods that are used for depth calculation, such as the inversion methods based on Parker's forwarding calculation technique [15]. But the methods requires manual matching of anomalies to curve-types, which is time consuming and is restricted to the anomaly types for which curves exist, unlike the spectral method [16]. Developed a depth determination method which matches two dimensional power spectral calculated from gridded total magnetic intensity field data with corresponding spectral obtained from a theoretical model. For the purpose of analyzing aeromagnetic data, the ground is as- 
sumed to consist of a number of independent ensembles of rectangular, vertical sided parallelepiped, and each is ensemble characterized by a joint frequency distribution for the depth (h) and length (b) and depth extent $(\mathrm{t})$.

In this work, the characteristics of the residual magnetic field was studied using statistical spectral method. This was done by first transforming the data from space to the frequency domain and then analyzing their frequency characteristics. In the general case, the radial spectrum may be conveniently approximated by straight line segments, the slopes of which relate to depths of the possible layers, [16] and [17]. The residual total magnetic field intensity values are used to obtain the two dimensional Fourier Transform, from which the spectrum is to be extracted from the residual values $T(X, Y)$ consisting of $M$ rows and $N$ columns in $X-Y$. The evaluation is done using an algorithm that is a two dimensional extension of the fast Fourier transform [18]. Next, the frequency intervals are subdivided into sub-intervals, which lie within one unit of frequency range. The average spectrum of the partial values together constitutes the radial spectrum of the anomalous field [17], and [13].

The logarithm of the energy values versus frequency on a linear scale was plotted and the linear segments located the truncation effect (or Gibbs phenomenon). Three or two linear segments could be seen from the graphs. The first points on the frequency scale was ignored because the low frequency components in the energy spectrum are generated from the deepest layers whose locations are most likely in errors, each linear segment groups points due to anomalies caused by bodies occurring within a particular depth. If $z$ is the mean depth of the layer, the depth factor for this ensemble of anomalies is $\exp (-2 z k)$. Thus the logarithmic plot of the radial spectrum would give a straight line whose slope is $-2 z$.

The mean depth of the burial ensemble is thus given as

$$
Z=-\frac{m}{2}
$$

where $(m)$ is the slope of the best fitting straight line. Equation (3) can be applied directly if the frequency unit is in radian per kilometer. If however, the frequency unit is in circle per kilometer, the corresponding relationship can be expressed as

$$
Z=-\frac{m}{4 \pi}
$$

In this study the aeromagnetic data set was divided into a block of $7.5^{\prime} \times 7.5^{\prime}$ $(13.73 \mathrm{~km} \times 13.73 \mathrm{~km})$ data points totaling 252 blocks excluding the Niger Republic part, which was subjected to Fast Fourier transformation (FFT) to compute the power spectrum of the magnetic data using Oasis montaj software.

\section{Results and Discussion}

\subsection{Results}

\subsubsection{Total Magnetic Intensity Map}

The total magnetic intensity map (Figure 3 ) of the study area was subdivided 


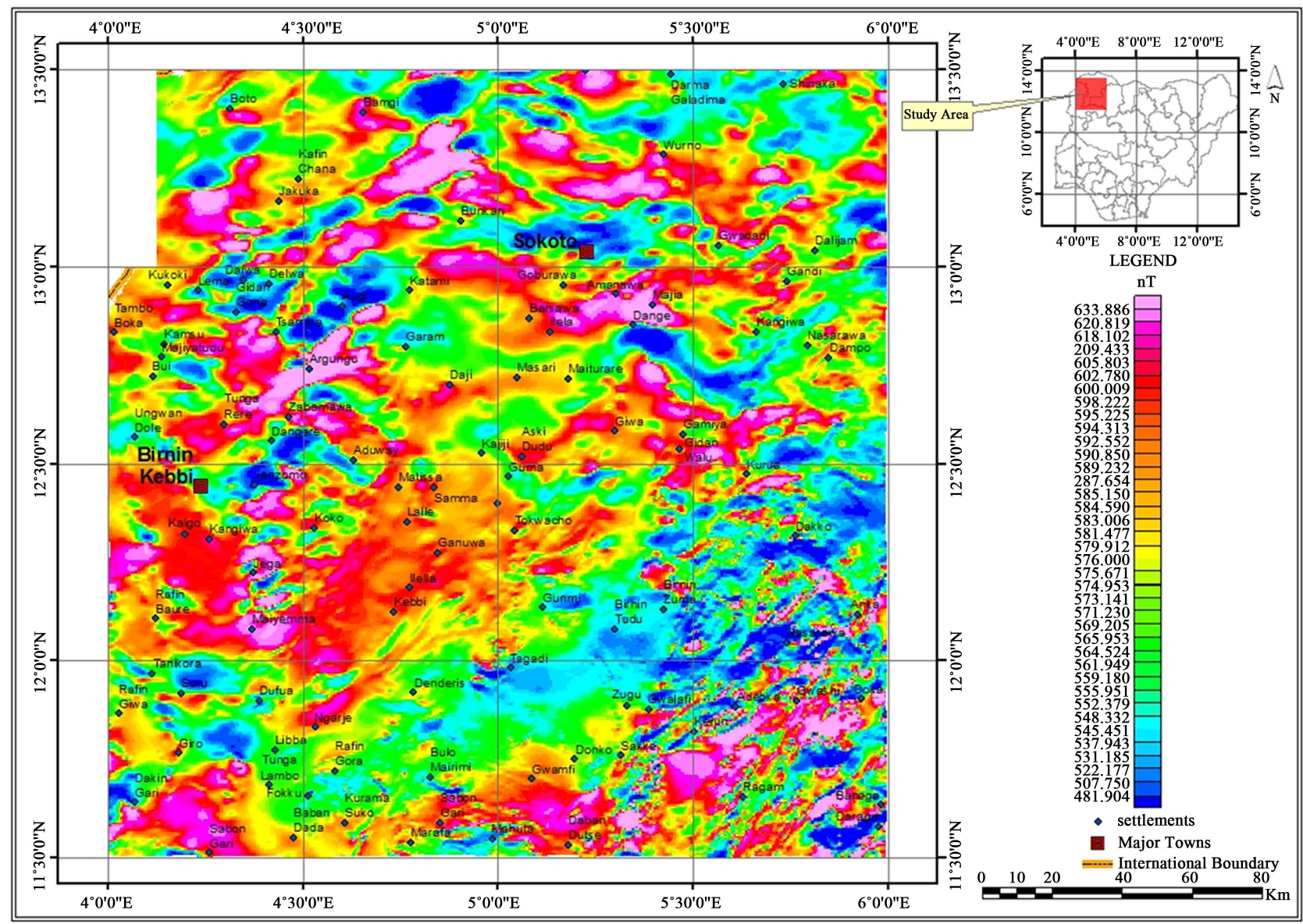

Figure 3. Total magnetic intensity map of the study area.

into three main sections: The northern part is characterized by low magnetic intensity values indicated by dark-light-blue-green-colour, while the eastern, western as well as the southern parts of the study area are characterized by low magnetic intensity values having dark-light-blue-green-colour dominating the area. The south western and south eastern parts of the study area are dominated by high magnetic intensity values, with pockets of reddish-pink colours disseminated in the northern part. Yellowish-orange-colours accompany the reddish-pink-colours depicting medium magnetic intensity values. The lowest total magnetic intensity value of the study area is $481.4 \mathrm{nT}$ and highest value of 633.9 nT (Figure 3).

\subsubsection{Residual Magnetic Intensity Map}

The residual magnetic map (Figure 4), show magnetic anomalies with high magnetic intensity value of $59.6 \mathrm{nT}$ and a low magnetic intensity value of -81.2 $\mathrm{nT}$. The pink colour anomalies have magnetic intensity ranging from $34.6 \mathrm{nT}$ to $59.6 \mathrm{nT}$ which are prominent in the northern and eastern parts, with pockets in the southwestern part. Red colour anomalies vary from $13.3 \mathrm{nT}$ to $30.7 \mathrm{nT}$ and are dominant in the northern, central and southwestern parts, with pockets of disseminations in the south-eastern parts. Yellow colour anomalies range from 


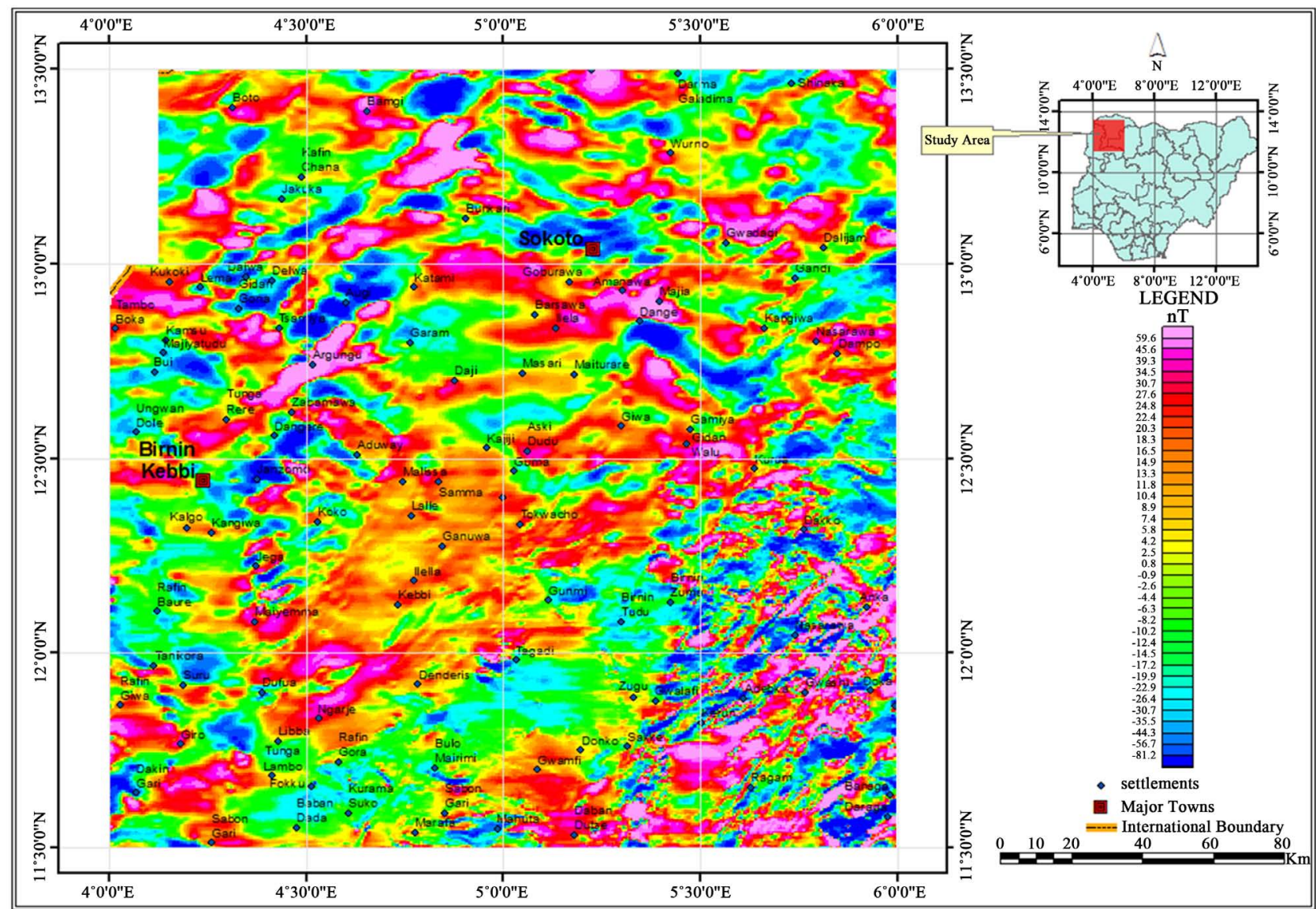

Figure 4. Residual magnetic intensity map of the study area.

$2.5 \mathrm{nT}$ to $11.8 \mathrm{nT}$ and occur along the red colour anomalies, dominating the entire map. Green colour anomalies are found in the northern, southeastern, northeastern and south-western parts, with pockets of small occurrences in the south-south which varies from $-17.2 \mathrm{nT}$ to $0.8 \mathrm{nT}$. Blue colour anomalies range from $-81.2 \mathrm{nT}$ to $-19.9 \mathrm{nT}$ and are the most dominant, occurring in almost every part of the map. The residual magnetic map was divided into 252 blocks which were subjected into Fourier Transform, to obtain the radially average power spectrum (Figure 5).

\subsubsection{Graphs of Spectral Analysis}

The logarithm of spectral energies was plotted against obtained frequencies for the various blocks (Figure 6). The depth of the deeper magnetic sources (D1), and the depth to the shallow magnetic sources (D2) of that distribution from the slope of the second longest wave length segment was calculated. The deeper sources ranges from $0.41 \mathrm{~km}$ to $2.69 \mathrm{~km}$, while the shallow sources ranges from $0.17 \mathrm{~km}$ to $0.97 \mathrm{~km}$ respectively. Table 1 shows the summary of the depths (D1 and D2). The results of D1 and D2 was contoured to produce contoured maps for D1 (Figure 7) and D2 (Figure 8) accompanied with coloured areas showing sub-basins that were identified in the study area. The contoured D1 was superimposed on the Geologic map of the study area (Figure 9). 
Table 1. Summary of Deeper (D1) and Shallow (D2) Magnetic source depth obtained from spectral analysis of residual magnetic map of the study area.

\begin{tabular}{|c|c|c|}
\hline Blocks & Deeper Sources (D1) & Shallow Sources (D2) \\
\hline Block 1 & 1.48 & 0.17 \\
\hline Block 2 & 1.27 & 0.38 \\
\hline Block 3 & 1.38 & 0.21 \\
\hline Block 4 & 1.38 & 0.23 \\
\hline Block 5 & 2.03 & 0.30 \\
\hline Block 6 & 1.98 & 0.33 \\
\hline Block 7 & 1.51 & 0.31 \\
\hline Block 8 & 1.48 & 0.39 \\
\hline Block 9 & 1.13 & 0.19 \\
\hline Block 10 & 2.09 & 0.71 \\
\hline Block 11 & 1.32 & 0.32 \\
\hline Block 12 & 1.30 & 0.38 \\
\hline Block 13 & 1.24 & 0.30 \\
\hline Block 14 & 1.52 & 0.72 \\
\hline Block 15 & 1.27 & 0.45 \\
\hline Block 16 & 1.35 & 0.55 \\
\hline Block 17 & 1.95 & 0.77 \\
\hline Block 18 & 1.92 & 0.97 \\
\hline Block19 & 1.31 & 0.54 \\
\hline Block 20 & 1.24 & 0.36 \\
\hline Block 21 & 1.06 & \\
\hline Block 22 & 1.38 & 0.50 \\
\hline Block 23 & 1.23 & 0.24 \\
\hline Block 24 & 1.56 & 0.59 \\
\hline Block 25 & 1.11 & 0.35 \\
\hline Block 26 & 1.73 & 0.66 \\
\hline Block 27 & 1.35 & 0.44 \\
\hline Block 28 & 1.28 & 0.30 \\
\hline Block 29 & 1.16 & 0.46 \\
\hline Block 30 & 1.40 & 0.65 \\
\hline Block 31 & 1.28 & 0.40 \\
\hline Block 32 & 1.74 & 0.66 \\
\hline Block 33 & 1.39 & 0.53 \\
\hline Block 34 & 1.36 & 0.54 \\
\hline Block 35 & 1.43 & 0.52 \\
\hline
\end{tabular}




\section{Continued}

\begin{tabular}{|c|c|c|}
\hline Block 36 & 1.83 & 0.88 \\
\hline Block 37 & 1.09 & 0.46 \\
\hline Block 38 & 1.39 & 0.28 \\
\hline Block 39 & 1.20 & 0.35 \\
\hline Block 40 & 1.19 & 0.27 \\
\hline Block 41 & 1.31 & 0.52 \\
\hline Block 42 & 1.34 & 0.78 \\
\hline Block 43 & 1.38 & 0.78 \\
\hline Block 44 & 1.52 & 0.80 \\
\hline Block 45 & 1.68 & 0.71 \\
\hline Block 46 & 1.41 & 0.42 \\
\hline Block 47 & 1.17 & 0.46 \\
\hline Block 48 & 1.28 & 0.46 \\
\hline Block 49 & 1.37 & 0.50 \\
\hline Block 50 & 2.69 & 0.71 \\
\hline Block 51 & 1.43 & 0.82 \\
\hline Block 52 & 1.47 & 0.57 \\
\hline Block 53 & 1.67 & 0.74 \\
\hline Block 54 & 1.07 & 0.19 \\
\hline Block 55 & 1.20 & 0.27 \\
\hline Block 56 & 1.16 & 0.25 \\
\hline Block 57 & 1.20 & 0.46 \\
\hline Block 58 & 1.24 & 0.70 \\
\hline Block 59 & 1.11 & 0.58 \\
\hline Block 60 & 1.72 & 0.60 \\
\hline Block 61 & 1.64 & 0.75 \\
\hline Block 62 & 1.79 & 0.73 \\
\hline Block 63 & 1.21 & 0.26 \\
\hline Block 64 & 1.08 & 0.56 \\
\hline Block 65 & 1.15 & 0.51 \\
\hline Block 66 & 1.34 & 0.59 \\
\hline Block 67 & 1.60 & 0.66 \\
\hline Block 68 & 1.19 & 0.34 \\
\hline Block 69 & 1.58 & 0.56 \\
\hline Block 70 & 1.43 & 0.61 \\
\hline Block 71 & 1.07 & 0.29 \\
\hline Block 72 & 1.27 & 0.67 \\
\hline
\end{tabular}




\section{Continued}

\begin{tabular}{|c|c|c|}
\hline Block 73 & 1.39 & 0.49 \\
\hline Block 74 & 0.89 & 0.50 \\
\hline Block 75 & 1.10 & 0.67 \\
\hline Block 76 & 1.12 & 0.57 \\
\hline Block 77 & 1.41 & 0.60 \\
\hline Block 78 & 1.30 & 0.36 \\
\hline Block 79 & 1.26 & 0.61 \\
\hline Block 80 & 1.14 & 0.36 \\
\hline Block 81 & 1.38 & 0.61 \\
\hline Block 82 & 1.27 & 0.26 \\
\hline Block 83 & 1.74 & 0.64 \\
\hline Block 84 & 2.02 & 0.92 \\
\hline Block 85 & 1.71 & 0.71 \\
\hline Block 86 & 1.22 & 0.34 \\
\hline Block 87 & 1.76 & 0.84 \\
\hline Block 88 & 1.93 & 0.85 \\
\hline Block 89 & 2.41 & 0.90 \\
\hline Block 90 & 0.85 & \\
\hline Block 91 & 1.40 & 0.71 \\
\hline Block 92 & 2.26 & 0.72 \\
\hline Block 93 & 1.36 & 0.65 \\
\hline Block 94 & 1.37 & 0.74 \\
\hline Block 95 & 1.12 & 0.49 \\
\hline Block 96 & 1.07 & 0.35 \\
\hline Block 97 & 1.58 & 0.85 \\
\hline Block 98 & 1.14 & 0.61 \\
\hline Block 99 & 1.29 & 0.32 \\
\hline Block 100 & 1.79 & 0.88 \\
\hline Block 101 & 1.58 & 0.24 \\
\hline Block 102 & 1.34 & 0.69 \\
\hline Block 103 & 1.13 & 0.72 \\
\hline Block 104 & 1.27 & 0.58 \\
\hline Block 105 & 1.46 & 0.71 \\
\hline Block 106 & 1.44 & 0.72 \\
\hline Block 107 & 1.11 & 0.70 \\
\hline Block 108 & 1.20 & 0.60 \\
\hline Block 109 & 1.17 & 0.44 \\
\hline Block 110 & 1.35 & 0.77 \\
\hline
\end{tabular}




\section{Continued}

\begin{tabular}{|c|c|c|}
\hline Block 111 & 1.17 & 0.48 \\
\hline Block 112 & 1.28 & 0.48 \\
\hline Block 113 & 1.20 & 0.39 \\
\hline Block 114 & 1.24 & 0.50 \\
\hline Block 115 & 1.15 & 0.72 \\
\hline Block 116 & 1.67 & 0.78 \\
\hline Block 117 & 1.63 & 0.70 \\
\hline Block 118 & 1.61 & 0.76 \\
\hline Block 119 & 1.26 & 0.35 \\
\hline Block 120 & 1.16 & 0.50 \\
\hline Block 121 & 1.42 & 0.58 \\
\hline Block 122 & 0.95 & 0.50 \\
\hline Block 123 & 1.16 & 0.59 \\
\hline Block 124 & 0.76 & 0.41 \\
\hline Block 125 & 1.84 & 0.82 \\
\hline Block 126 & 1.36 & 0.37 \\
\hline Block 127 & 1.22 & 0.50 \\
\hline Block 128 & 1.34 & 0.52 \\
\hline Block 129 & 1.37 & 0.60 \\
\hline Block 130 & 1.30 & 0.57 \\
\hline Block 131 & 1.14 & 0.51 \\
\hline Block 132 & 0.17 & 0.25 \\
\hline Block 133 & 1.60 & 0.90 \\
\hline Block 134 & 1.23 & 0.43 \\
\hline Block 135 & 1.29 & 0.49 \\
\hline Block 136 & 1.21 & 0.59 \\
\hline Block 137 & 0.88 & 0.38 \\
\hline Block 138 & 1.27 & 0.62 \\
\hline Block 139 & 0.67 & \\
\hline Block 140 & 0.64 & \\
\hline Block 141 & 1.25 & 0.41 \\
\hline Block 142 & 2.05 & 0.72 \\
\hline Block 143 & 1.22 & 0.62 \\
\hline Block 144 & 1.14 & 0.68 \\
\hline Block 145 & 0.99 & 0.36 \\
\hline Block 146 & 1.13 & 0.55 \\
\hline Block 147 & 0.98 & 0.37 \\
\hline
\end{tabular}




\section{Continued}

\begin{tabular}{|c|c|c|}
\hline Block 148 & 0.72 & \\
\hline Block 149 & 0.75 & \\
\hline Block 150 & 0.96 & 0.55 \\
\hline Block 151 & 0.85 & \\
\hline Block 152 & 1.02 & 0.51 \\
\hline Block 153 & 0.90 & 0.42 \\
\hline Block 154 & 0.99 & 0.47 \\
\hline Block 155 & 0.52 & \\
\hline Block 156 & 1.37 & 0.46 \\
\hline Block 157 & 0.79 & \\
\hline Block 158 & 1.72 & 0.56 \\
\hline Block 159 & 1.02 & 0.47 \\
\hline Block 160 & 0.73 & \\
\hline Block 161 & 0.77 & \\
\hline Block 162 & 1.52 & 0.23 \\
\hline Block 163 & 1.29 & 0.64 \\
\hline Block 164 & 1.00 & 0.53 \\
\hline Block 165 & 1.09 & 0.53 \\
\hline Block 166 & 1.41 & 0.59 \\
\hline Block 167 & 0.79 & 0.31 \\
\hline Block 168 & 1.08 & 0.56 \\
\hline Block 169 & 0.65 & 0.39 \\
\hline Block 170 & 0.54 & \\
\hline Block 171 & 0.89 & 0.40 \\
\hline Block 172 & 0.86 & 0.41 \\
\hline Block 173 & 0.83 & 0.45 \\
\hline Block 174 & 1.37 & 0.69 \\
\hline Block 175 & 1.16 & 0.65 \\
\hline Block 176 & 1.19 & 0.56 \\
\hline Block 177 & 1.67 & 0.56 \\
\hline Block 178 & 1.21 & 0.60 \\
\hline Block 179 & 1.23 & 0.59 \\
\hline Block 180 & 1.18 & 0.38 \\
\hline Block 181 & 1.04 & 0.34 \\
\hline Block 182 & 1.19 & 0.51 \\
\hline
\end{tabular}




\section{Continued}

\begin{tabular}{|c|c|c|}
\hline Block 183 & 1.81 & 0.44 \\
\hline Block 184 & 0.62 & 0.33 \\
\hline Block 185 & 0.56 & \\
\hline Block 186 & 0.65 & 0.42 \\
\hline Block 187 & 0.49 & \\
\hline Block 188 & 0.51 & \\
\hline Block 189 & 1.06 & 0.44 \\
\hline Block 190 & 1.59 & 0.61 \\
\hline Block 191 & 1.15 & 0.49 \\
\hline Block 192 & 0.71 & \\
\hline Block 193 & 1.44 & 0.61 \\
\hline Block 194 & 1.21 & 0.59 \\
\hline Block 195 & 0.72 & \\
\hline Block 196 & 0.63 & \\
\hline Block 197 & 0.91 & 0.35 \\
\hline Block 198 & 1.26 & 0.66 \\
\hline Block 199 & 0.90 & 0.39 \\
\hline Block 200 & 0.77 & 0.49 \\
\hline Block 201 & 0.58 & \\
\hline Block 202 & 0.81 & 0.35 \\
\hline Block 203 & 1.03 & 0.46 \\
\hline Block 204 & 0.51 & \\
\hline Block 205 & 1.01 & 0.28 \\
\hline Block 206 & 1.18 & 0.56 \\
\hline Block 207 & 1.54 & 0.54 \\
\hline Block 208 & 1.70 & 0.38 \\
\hline Block 209 & 1.43 & 0.57 \\
\hline Block 210 & 0.64 & \\
\hline Block 211 & 1.12 & 0.5 \\
\hline Block 212 & 1.02 & 0.48 \\
\hline Block 213 & 1.70 & 0.32 \\
\hline Block 214 & 1.56 & 0.51 \\
\hline Block 215 & 0.64 & \\
\hline Block 216 & 0.62 & \\
\hline Block 217 & 0.52 & \\
\hline
\end{tabular}




\section{Continued}

\begin{tabular}{|c|c|c|}
\hline Block 218 & 0.79 & 0.39 \\
\hline Block 219 & 1.91 & 0.34 \\
\hline Block 220 & 0.87 & 0.45 \\
\hline Block 221 & 1.32 & 0.67 \\
\hline Block 222 & 1.13 & 0.48 \\
\hline Block 223 & 2.05 & 0.57 \\
\hline Block 224 & 2.60 & 0.60 \\
\hline Block 225 & 0.62 & 0.33 \\
\hline Block 226 & 0.52 & \\
\hline Block 227 & 0.57 & \\
\hline Block 228 & 0.62 & \\
\hline Block 229 & 1.04 & 0.41 \\
\hline Block 230 & 1.05 & 0.47 \\
\hline Block 231 & 0.56 & \\
\hline Block 232 & 0.41 & \\
\hline Block 233 & 0.58 & \\
\hline Block 234 & 1.19 & 0.45 \\
\hline Block 235 & 1.05 & 0.42 \\
\hline Block 236 & 0.81 & 0.48 \\
\hline Block 237 & 1.23 & 0.62 \\
\hline Block 238 & 1.12 & 0.46 \\
\hline Block 239 & 1.27 & 0.43 \\
\hline Block 240 & 1.63 & 0.45 \\
\hline Block 241 & 0.84 & 0.30 \\
\hline Block 242 & 0.44 & \\
\hline Block 243 & 0.49 & \\
\hline Block 244 & 0.85 & 0.41 \\
\hline Block 245 & 0.56 & \\
\hline Block 246 & 0.48 & \\
\hline Block 247 & 1.42 & 0.48 \\
\hline Block 248 & 1.02 & 0.43 \\
\hline Block 249 & 0.87 & 0.40 \\
\hline Block 250 & 1.43 & 0.46 \\
\hline Block 251 & 0.93 & 0.40 \\
\hline Block 252 & 0.54 & \\
\hline
\end{tabular}




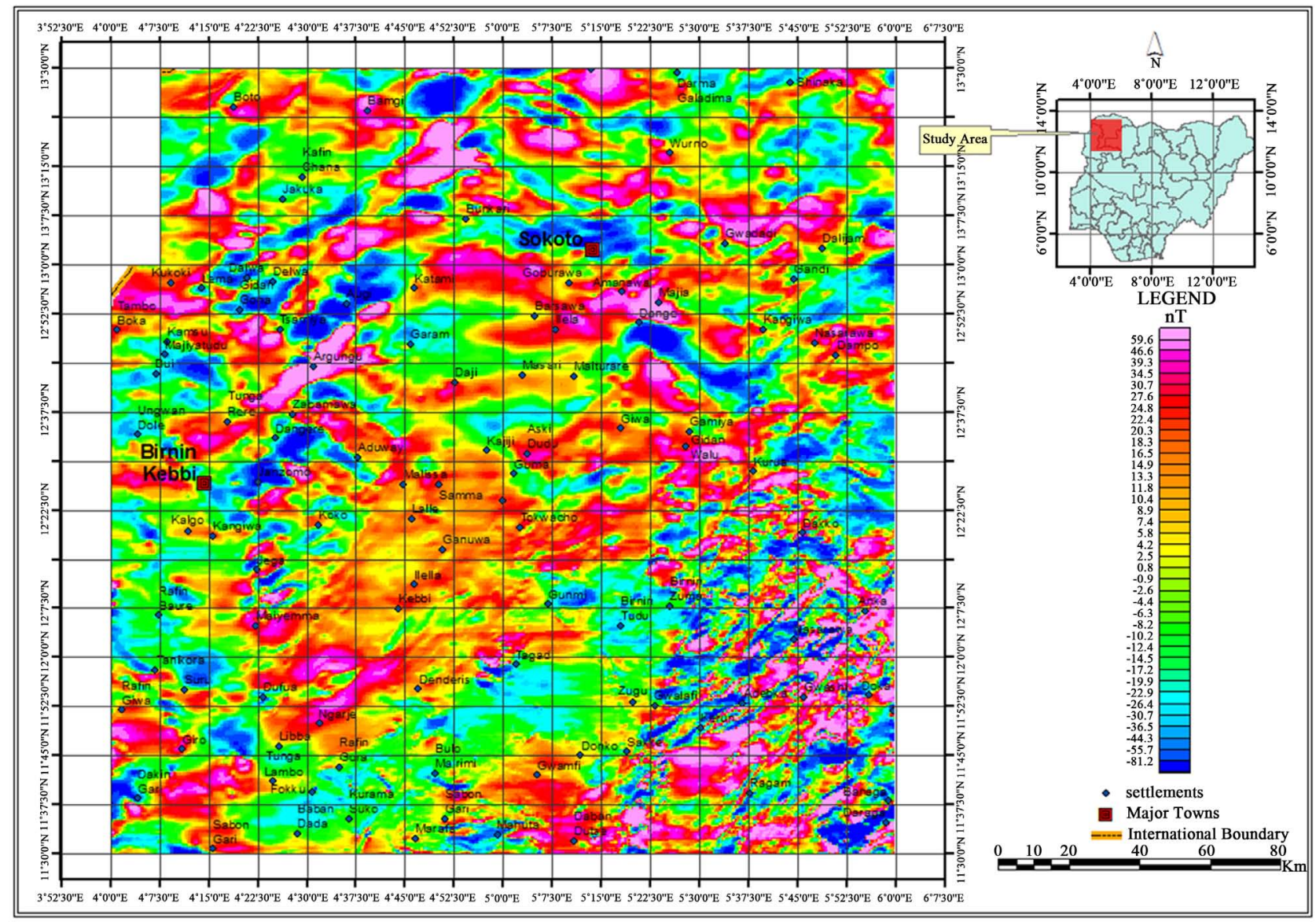

Figure 5. Gridded residual magnetic intensity map of Sokoto basin showing the 252 blocks that were subjected to fast fourier transformation to obtain the depth to magnetic source.

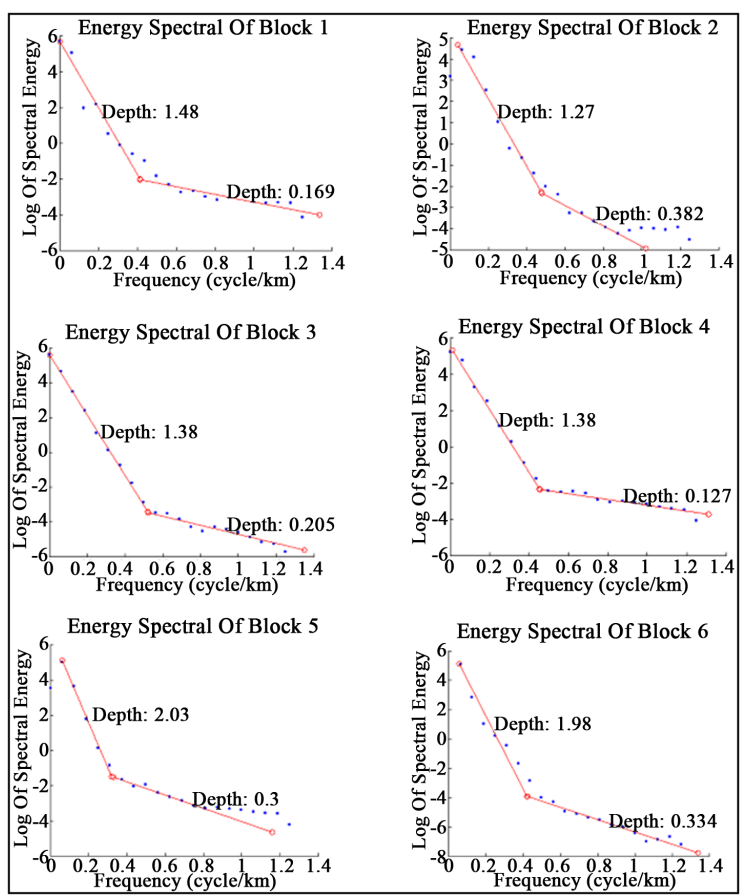

Figure 6. Examples of graphs of spectral blocks obtained in the study area. 


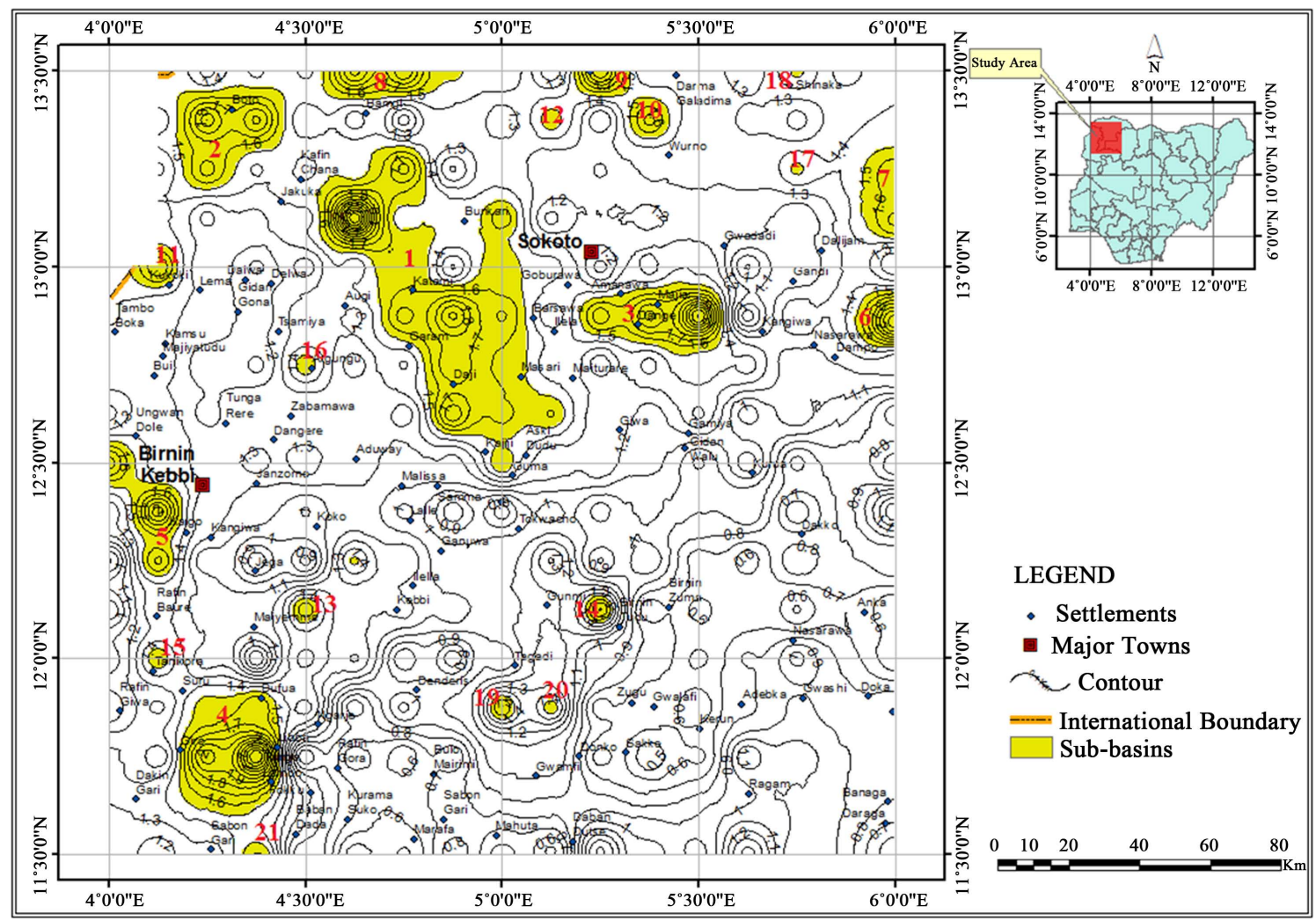

Figure 7. Magnetic source depths (deeper sources D1) contoured map of the study area (Cont. Int. $0.1 \mathrm{~km}$ ).

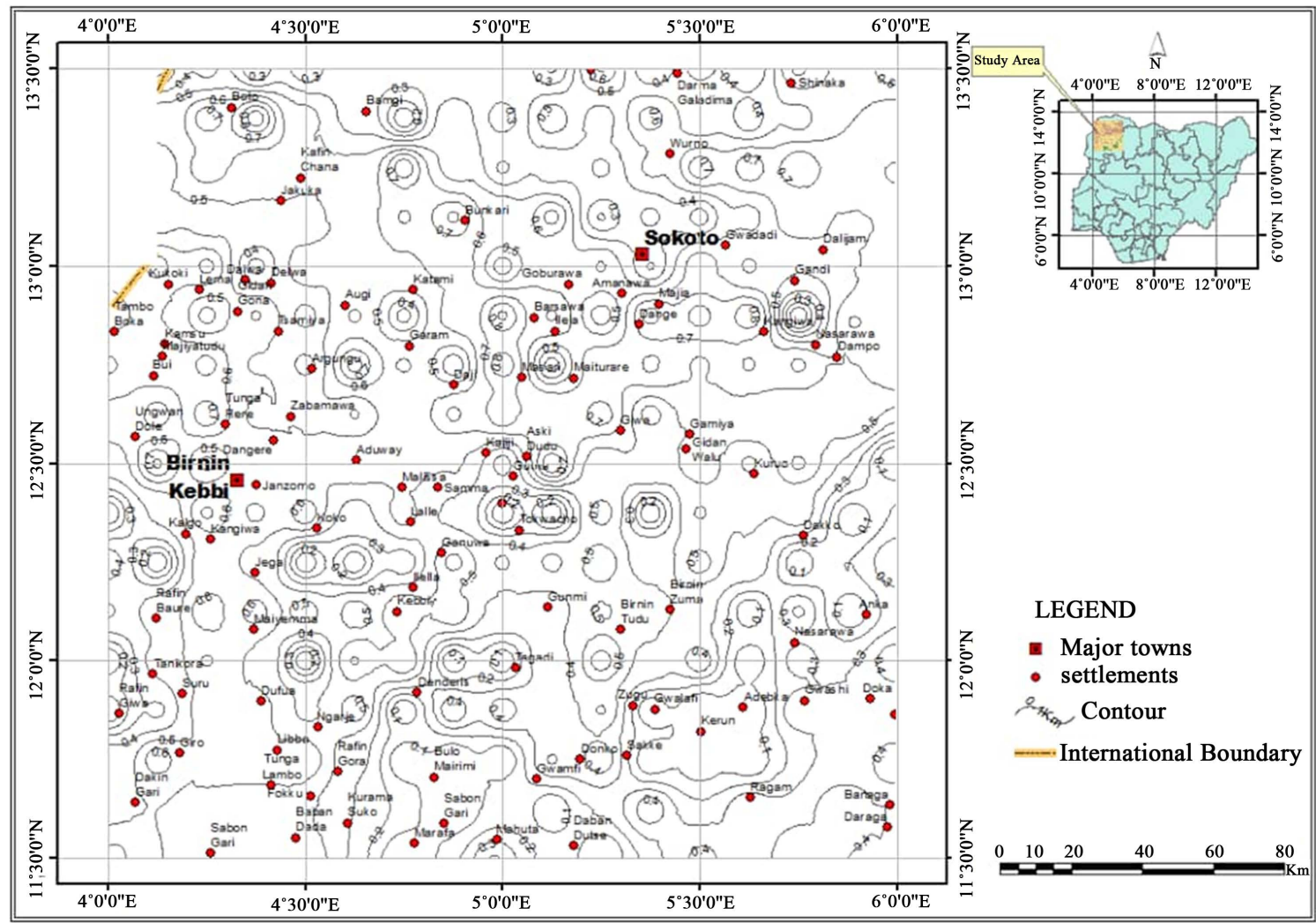

Figure 8. Magnetic source depths (shallow sources D2) contoured map of the study area (Cont. Int. $0.1 \mathrm{~km}$ ). 


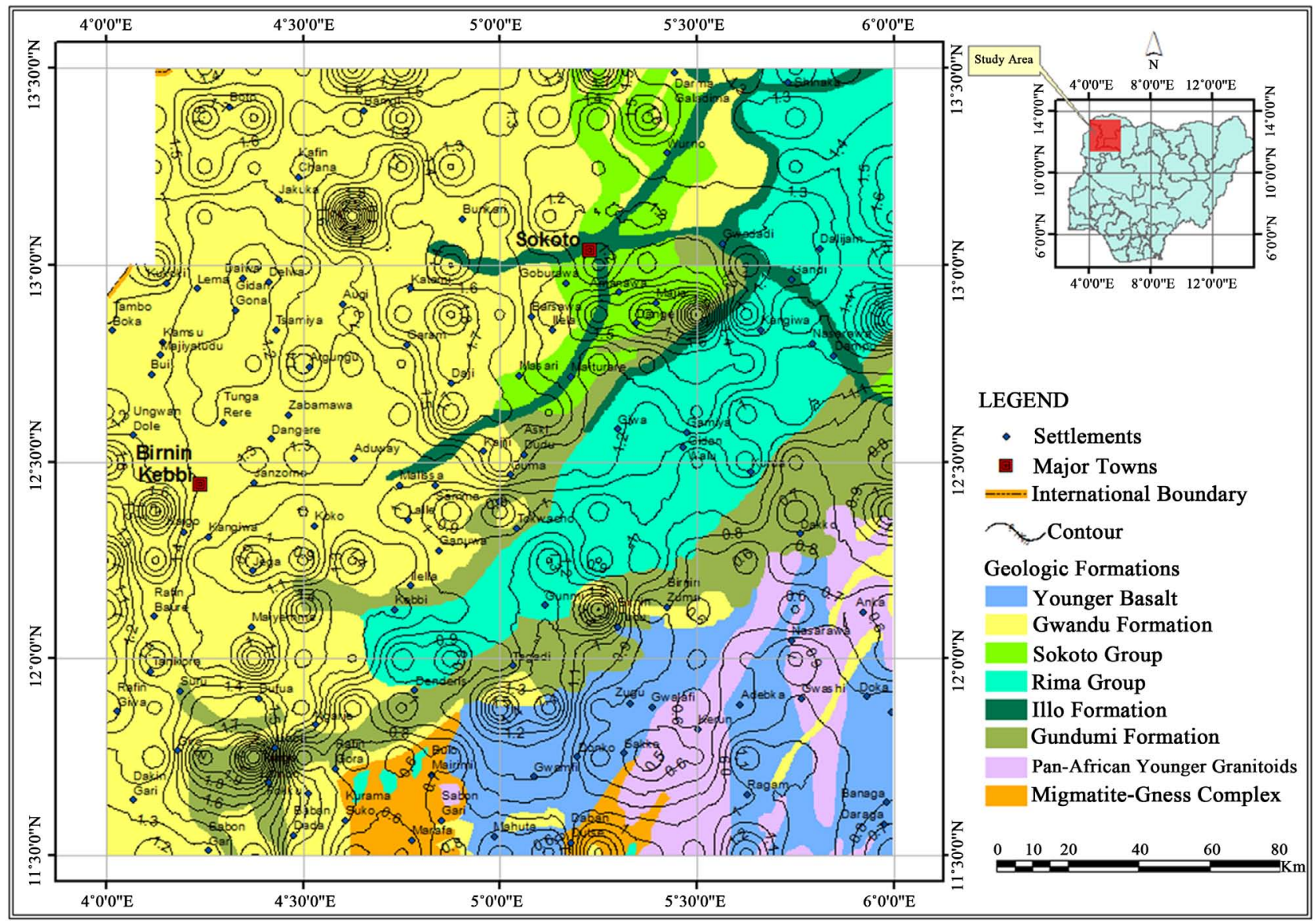

Figure 9. Deeper magnetic source depth (D1) super imposed on the Geologic Map of the study area.

\subsection{Discussion}

From the spectral analysis (Figure 7) various depths of D1, the summary of the result of the depths is presented in Table 1. A careful observation of the D1 map revealed Sub-Basins based on the various depths that were observed in the area. These depths are similar to ones obtained by [10] and [4]. The coloured areas on Figure 7 are regarded as sub-basins because of their depth and thus high sediment thickness from $1.5 \mathrm{~km}$ and above. These are the possible potential areas for further hydrocarbon exploration. Though the result of the shallow Magnetic source depth (D2) shows that the basin is shallow with few identified areas of considerable depth indicating probable near surface igneous intrusions in the basin [10].

The major sub-basins identified include: sub-basin 1, with an approximate width of $43 \mathrm{~km}$ and length of $71 \mathrm{~km}$; sub-basin 2, with an approximate width of $29 \mathrm{~km}$ and length of $31 \mathrm{~km}$; sub-basin 3, with an approximate width of $20 \mathrm{~km}$ and length of $41 \mathrm{~km}$; sub-basin 4, approximately $32 \mathrm{~km}$ in width and $39 \mathrm{~km}$ in length; sub-basin 5, with an approximate width of $19 \mathrm{~km}$ and length of $45 \mathrm{~km}$; sub-basin 8, with an approximate width of $7 \mathrm{~km}$ and length of $40 \mathrm{~km}$.

The result of the contoured deeper magnetic source depth (D1) was super imposed on the geologic map (Figure 9) to further observe the relationship of 
the sediments thickness and geology of the area. This shows that the sediment over burden are of shallow depth in the basement compared to the sedimentary area. Most of the areas with high sediment thickness were observed on the Gwandu Formation. The shales of Dange, Kalambaina and Dukamaje Formations could be the source rocks, while grits and sandstones of Taloka and Wurno Formations could serve as the reservoir rock.

\section{Conclusions and Recommendations}

\subsection{Conclusions}

The following conclusions can be drawn from this study:

1) Spectral analysis indicates that the basin is characterized by shallow and deeper sediments thickness.

2) Areas with shallow thickness of sediments, could not allow thermal maturation of the sediments, since temperature increase with depth. Depth of $2 \mathrm{~km}$ and above has a temperature range of $60^{\circ} \mathrm{C}$ and above. The oil window according to [1] varies between $60^{\circ} \mathrm{C}$ and $120^{\circ} \mathrm{C}$, above the temperature of $120^{\circ} \mathrm{C}$ the oil may be thermally cracked to gas, and bellow $60^{\circ} \mathrm{C}$, it will form kerogen. Therefore areas with sediment thickness from $2 \mathrm{~km}$ and above could be good potential sites for hydrocarbon exploration.

\subsection{Recommendations}

The study area if given much attention, will add to the economic growth of Nigeria based on the hydrocarbon potentials revealed by this study. Therefore the use of other geophysical methods such as seismic and well logging is highly useful.

\section{Acknowledgements}

The author is grateful to the Nigerian Geological Survey Agency (NGSA), for releasing the High Resolution Digital Aeromagnetic data at a subsidized rate and Adamawa State University, Mubi Nigeria, for granting the author a study fellowship.

\section{References}

[1] Nwanko, L.I. (2007) Spectral Evaluation of Aeromagnetic Anomaly Map for Geothermal Exploration in Part of Nupe Basin, West Central Nigeria. PhD Thesis, University of Ilorin, Ilorin.

[2] Reynolds, J.M. (1990) An Introduction to Applied and Environmental Geophysics. John Wiley and Sons Limited, Hoboken, 116-207.

[3] Abdulsalam, N.N., Nasir, M.A. and Likason, K.O. (2011) Identification of Linear Features Using Continuation Filters over Koton Karfi Area from Aeromagnetic Data. World Rural Observation, 3, 1-8.

[4] Obaje, G.N., Aduku, M. and Yusuf, L. (2013) The Sokoto Basin of Northwestern Nigeria: A Preliminary Assessment of the Hydrocarbon Prospectivity. Petroleum Technology Development Journal, 3, 66-80. 
[5] Digital Elevation Model (2006) Topographical Map of Latitude $11^{\circ} 30^{\prime} \mathrm{N}-13^{\circ} 30^{\prime} \mathrm{N}$ and Longitude $4^{\circ} 00^{\prime} \mathrm{E}-6^{\circ} 00^{\prime} \mathrm{E}$.

[6] Kogbe, C.A. (1976) Outline of the Geology of Illummeden Basin, Geology of Nigeria. Elizabethan Publishing Co., 331-338.

[7] Affodile, M.E. (2002) Ground Water Study and Development in Nigeria. 2nd Edition, Mecon Geology and Eng., Services Ltd., Jos, 453 p.

[8] Jones, B. (1948) Sedimentary Rocks of the Sokoto Province. Bulletin of the Geological Survey of Nigeria, Vol. 18, Kaduna, 79 p.

[9] Parker, D.H., Fargher Carter, M.N. and Turner, O.C. (1964) Geological Map of Nigeria Series 1:250,000.

[10] Bonde, D.S., Udensi, E.E. and Rai, J.K. (2014) Spectral Depth Analysis of Sokoto Basin. Journal of Applied Physics, 6, 15-21.

[11] Nigerian Geological Survey Agency, NGSA (2006) Geological Map of Latitude $11^{\circ} 30^{\prime}-13^{\circ} 30^{\prime}$ and Longitude $4^{\circ} 00^{\prime}$ and $6^{\circ} 00^{\prime}$.

[12] Nigeria Geological Survey Agency, NGSA (2010) High Resolution Aeromagnetic Data, (16 Sheets), Latitude $11^{\circ} 30^{\prime}-13^{\circ} 30^{\prime}$ and Longitude $4^{\circ} 00^{\prime}-6^{\circ} 00^{\prime}$.

[13] Udensi, E.E. (2001) Interpretation of Total Magnetic Field over the Nupe Basin and the Surrounding Basement Complex, Using Aeromagnetic Data. Unpublished PhD Thesis, Ahmadu Bello University, Zaria.

[14] Oasis montaj 7.0.1 QX Geosoft Inc. Queens Quay Terminal, 207 Queens Quay West Suit 810

[15] Parker Gay, S. (1963) Standard Curves for Interpreting Magnetic Anomalies over Long Tabular Bodies. Geophysics, 28, 161-200. https://doi.org/10.1190/1.1439164

[16] Spector, A. and Grant, F.S. (1970) Statistical Models for Interpreting Aeromagnetic Data. Geophysics, 35, 461-470. https://doi.org/10.1190/1.1440092

[17] Hahn, A., Kind, E.G. and Mishara, D.C. (1976) Depth Estimation of Magnetic Sources by Means of Fourier Amplitude Spectra. Geophysical Prospecting, 24, 287-308. https://doi.org/10.1111/j.1365-2478.1976.tb00926.x

[18] Oppenheim, A.V. and Schafer, R.W. (1975) Digital Signal Processing Practice. Hall International Inc., 1227-1296. 